\title{
Influence of Canopy Characteristics of One-seed Juniper on Understory Grasses
}

\author{
M.R. SCHOTT AND R.D. PIEPER
}

\begin{abstract}
Studies were conducted in the Sacramento Mountains, New Mexico, to determine the influence of juniper (Juniperus monosperma [Engelm.] Sarg.) canopy on understory vegetation. The basal area of grass species was estimated at 6 locations beneath the canopies of 50 one-seed junipers. Other parameters measured were litter depth, canopy height, canopy cover, canopy closure, tree height, trunk diameter, north-south crown diameter, and east-west crown diameter. Locations adjacent to the trunk had the greatest juniper canopy cover and litter depths, and the lowest height to canopy. Locations at the end of the canopy had the least crown cover and litter depths, and the greatest height to canopy. All but one of the grass species had greater basal areas at the edge locations and the least at the interior locations beneath juniper canopies. Pinyon ricegrass (Piptochaetium fimbriatum [H.B.K.] Hitch.) was the exception; it was never found at the exterior locations. Regression models indicated that shading influenced the basal areas of most grass species. Litter depth was negatively correlated with grass basal cover in only 4 models and positively correlated in 1. Basal area of pinyon ricegrass was positively correlated with trunk diameter, a reflection of tree age, indicating that the grass requires time to become established. Also, basal area of pinyon ricegrass was positively correlated with canopy cover, indicating that this species requires the modified microenvironment afforded by shading.
\end{abstract}

Pinyon-juniper communities occur on some $701,514 \mathrm{~km}^{2}$ in the southwestern United States (West et al. 1975). Since European settlement, these communities have increased both in area and tree density (West et al. 1975). There has been a concomitant decrease in production of understory species (Johnson 1962, Arnold 1964). This decrease is most apparent under the canopy of the junipers; as junipers get larger, the number of shrubs, forbs, and grasses decline (Springfield 1976). Lavin et al. (1968) found that decline of herbaceous species is particularly pronounced on heavy soils. Arnold

\footnotetext{
Authors are former graduate assistant and professor, Department of Animal and

Range Sciences, New Mexico State University, Las Cruces $\mathbf{8 8 0 0 3 .}$

This is Journal Article 1102 of the New Mexico Agr. Exp. Sta.

Manuscript accepted November 29, 1984.
}

(1964) and Jameson (1970) reported reduction in blue grama (Bouteloua gracilis [H.B.K.] Lag.) in areas beyond the canopies of the junipers. Junipers have a large lateral root system that extends well past the crown (Jameson 1964). Both Arnold (1964) and Jameson (1970) attribute the blue gra ma decline to competition for soil moisture between this species and the junipers. Decline in understory production has been attributed to shading, water interception, litter accumulation, and allelopathy. Jameson (1965) and Lavin et al. (1968) reported an allelopathic effect of juniper leaves and litter on several grass species. Skau (1960) and Johnson (1962) found that juniper canopies intercept significant amounts of rain resulting in dry conditions under the canopy. Arnold (1964) and Jameson (1967) attributed some of the understory reduction, especially that of blue grama, to shading. In contrast, Jameson (1966) could detect no shading effect on grass cover, but did find that litter had a significant effect. Grass cover was generally greater near the canopy boundary than in interspaces between trees or beneath the canopy of singleleaf pinyon (Pinus monophylla Torr. \& Frem.) in Nevada (Everett et al. 1984). The objective of this study was to determine patterns of understory vegetation beneath juniper canopies.

\section{Material and Methods}

The study area was located on the Fort Stanton Experimental Ranch in the Sacramento Mountains of southcentral New Mexico. It has cool, dry winters and warm, moist summers with cool nights (Pieper et al. 1971). The average annual precipitation is $34.75 \mathrm{~cm}$ (Rippel 1978). About $65 \%$ of the annual precipitation falls from July through September. Junipers formed an open stand on a south-facing slope of 5-10\%. Blue grama was the dominant understory species. The soil was a Deacon soil series, which is a fineloamy, mixed, Aridic Haplustoll (Bailey et al. 1982). Fifty one-seed junipers with trunks ranging in diameter from 4 to $120 \mathrm{~cm}$ at ground level were selected randomly, except for the requirement that they be beyond the shading influence of other junipers.

Basal area of the grass species was estimated at 6 locations under each juniper. The north and south sides each were sampled at 3 
Table 1. Multiple comparisons of the means of the six locations using Fisher's LSD for canopy closure (\%) by densiometer and occular estimates, litter depths $(\mathrm{cm})$, and height of canopy $(\mathrm{cm})$.

\begin{tabular}{|c|c|c|c|c|}
\hline \multirow[b]{3}{*}{ Location } & \multicolumn{4}{|c|}{ Estimates of Canopy Closure (\%) } \\
\hline & Densiometer & Occular & Litter Depth & Ht. of Canopy \\
\hline & $\%$ & $\%$ & $\mathrm{~cm}$ & $\mathrm{~cm}$ \\
\hline S. Center & $91.26 \mathrm{~A}^{1}$ & $88.80 \mathrm{~A}$ & $4.3 \mathrm{~A}$ & $32.26 \mathrm{C}$ \\
\hline N. Center & $88.90 \mathrm{AB}$ & $83.20 \mathrm{~B}$ & $3.97 \mathrm{AB}$ & $34.38 \mathrm{C}$ \\
\hline S. Middle & $85.98 \mathrm{~B}$ & $78.10 \mathrm{C}$ & $3.45 \mathrm{~B}$ & $49.08 \mathrm{BC}$ \\
\hline N. Middle & $80.88 \mathrm{C}$ & $72.70 \mathrm{D}$ & $2.42 \mathrm{C}$ & $69.28 \mathrm{AB}$ \\
\hline S. Edge & $39.06 \mathrm{D}$ & $48.30 \mathrm{E}$ & $0.48 \mathrm{D}$ & $83.38 \mathrm{~A}$ \\
\hline N. Edge & $32.76 \mathrm{E}$ & $43.10 \mathrm{~F}$ & $0.33 \mathrm{D}$ & $81.10 \mathrm{~A}$ \\
\hline
\end{tabular}

'Means followed by different letters are significantly different $(P<.0001)$.

locations: adjacent to the trunk, half the distance from the trunk to the edge of the canopy, and at the edge of the canopy. A $20 \times 50-\mathrm{cm}$ frame was used to estimate basal area. Litter depth and canopy height from the ground were measured for all locations under each tree. Two different estimates of canopy closure or cover were made at each location. A visual estimate was made by looking up through the canopy and estimating percent closure. A spherical densiometer was also used to estimate canopy closure (Lemmon 1956, Strickler 1959). The densiometer was read from the 4 cardinal directions; these readings were averaged and then multiplied by 1.02 to obtain a more accurate estimate. It proved impossible to read the interior positions from more than 3 directions. Consequently, readings were taken for 3 directions, averaged, and multiplied by 1.02 to obtain a closure estimate at each location. Several other tree parameters were also measured: height of each juniper, north-south crown diameter, east-west crown diameter, number of stems arising from the ground, trunk diameter at ground level, and the percent fullness of the canopy.

Analysis of variance was used to determine if there were differences among the 6 locations for canopy height, both estimates of canopy closure, litter depths, total grass basal area and basal area for each grass species. A protected Fisher's least significant difference (LSD) was used to compare means at each location (Ott 1977). A stepwise regression analysis was run for each location using grass basal area as the dependent variable and the other parameters as independent variables (Draper and Smith 1966). Variables were included in the model when they met the 0.05 significance level criterion. Interactions were tested for significance.

\section{Results and Discussion}

There were significant differences $(P<.0001)$ among the 6 locations under junipers for estimates of canopy height, canopy closure using both techniques, and litter depth (Table 1). Densiometer estimates of canopy closure were greater for the 2 locations adjacent to the trunk than the other locations. Of the remaining locations, those on the south side of the juniper trees had more canopy closure than those on the north side, indicating that foliage on the south side of the tree was thicker than on the north side. The visual canopy closure estimates confirmed this relationship. The main difference between the 2 results was that the visual method indicated that all locations on the south side had more foliage than comparable positions on the north side.

Comparisons of litter depth were similar to comparisons of the densiometer estimates. Locations adjacent to the trunk had greater accumulations of litter than most other locations (Table 1). The mid-canopy location on the south side of the junipers had greater litter accumulations than comparable locations on the north side. The canopy edge positions had least litter.

Positions near the canopy edge higher canopy heights than the other locations, and the positions adjacent to the trunk had the lowest canopy height (Table 1). There was little difference in canopy height between the north and south locations. Juniper branches typically grow out and up from the main stem.

Locations on the outside edge of the crown had higher grass cover than those adjacent to the trunk (Table 2). Total grass and blue grama basal areas differed for the mid-canopy positions, with the north position having more grass. Positions on the canopy edge, both north and south, had less canopy cover and litter accumulation than interior positions. Canopy height was greater at the canopy edge, thus grasses there likely receive more light. Canopy edge positions were influenced less by shading and litter cover than the under canopy locations, with the result that grass basal area was higher for these positions. The mid-canopy position on the south side of the junipers exhibited greater canopy closure and litter depths than the corresponding position on the north side, and supported less grass. This relationship suggests shading and litter both have a negative influence on blue grama, wolftail (Lycurus phleoides H.B.K.), and creeping muhly (Muhlenbergia repens [Presl.] Hitch.).

Pinyon ricegrass was the exception to the pattern found for other grasses. Highest basal area of pinyon ricegrass was found at the mid-canopy and trunk positions on the north side of the

Table 2. Multiple comparisons of the basal area (\%) of total grass, blue grama, wolftail, pinyon ricegrass and creeping muhly for the six locations, using fisher's LSD.

\begin{tabular}{|c|c|c|c|c|c|}
\hline \multirow[b]{3}{*}{ Location } & \multirow[b]{2}{*}{ Total Grass* } & \multicolumn{4}{|c|}{ Basal Area } \\
\hline & & Blue grama* & Wolftail*** & Pinyon ricegrass** & Creeping muhly* \\
\hline & $\%$ & $\%$ & $\%$ & $\%$ & $\%$ \\
\hline S. Edge & $35.18 \mathrm{~A}^{1}$ & $23.06 \mathrm{~A}$ & $2.36 \mathrm{~A}$ & $0.00 \mathrm{C}$ & $7.68 \mathrm{~A}$ \\
\hline N. Edge & $31.32 \mathrm{~A}$ & $23.84 \mathrm{~A}$ & $2.24 \mathrm{~A}$ & $0.00 \mathrm{C}$ & $4.30 \mathrm{AB}$ \\
\hline N. Middle & $22.72 \mathrm{~B}$ & $16.72 \mathrm{~B}$ & $0.18 \mathrm{~B}$ & $3.96 \mathrm{~A}$ & $1.26 \mathrm{BC}$ \\
\hline S. Middle & $13.68 \mathrm{C}$ & $9.56 \mathrm{C}$ & $0.44 \mathrm{AB}$ & $0.32 \mathrm{BC}$ & $2.34 \mathrm{BC}$ \\
\hline N. Center & $5.32 \mathrm{D}$ & $1.42 \mathrm{D}$ & $0.00 \mathrm{~B}$ & $2.30 \mathrm{AB}$ & $0.94 \mathrm{BC}$ \\
\hline S. Center & $2.58 \mathrm{D}$ & $1.40 \mathrm{D}$ & $0.00 \mathrm{~B}$ & $134 \mathrm{BC}$ & $0.00 \mathrm{C}$ \\
\hline
\end{tabular}

${ }^{1}$ Means followed by different letters are significantly different $(* R<.0001, * * P<.0018, * * * P<.0242)$ 
Table 3. Regression models for each location for total grass, blue grama, wolftail, pinyon ricegrass, and creeping muhly.

\begin{tabular}{|c|c|c|c|c|c|}
\hline Location & Total grass & Blue grama & Wolftail & Pinyon ricegrass & Creeping muhly \\
\hline \multirow[t]{2}{*}{ N. Center } & $\begin{array}{l}\mathrm{Y}=\mathbf{a}+\mathbf{b} T H T-b L I T- \\
\mathbf{b D E}^{1}\end{array}$ & $\mathrm{Y}=\mathrm{a}+\mathrm{bDIA} 1-\mathrm{bCCOV}$ & -2 & $\begin{array}{l}Y=a+b D I A 1-b D I A 2+ \\
\text { bBDIA-bCCLOS }+ \\
\text { bDE }\end{array}$ & $\mathrm{Y}=\mathrm{a}+\mathrm{bDIA2}-\mathrm{bLIT}-\mathrm{bDE}$ \\
\hline & $R^{2}=.477$ & $R^{2}=.306$ & & $R^{2}=.682$ & $R^{2}=.304$ \\
\hline \multirow[t]{2}{*}{ N. Middle } & $\begin{array}{c}\mathrm{Y}=\mathrm{a}+\mathrm{bDIA} 2-\mathrm{bCCOV}- \\
\mathrm{bLIT}+\mathrm{bHT}\end{array}$ & $\mathrm{Y}=\mathrm{a}+\mathrm{bDIA2}-\mathrm{bLIT}$ & $Y=a-b D I A l$ & $Y=a+b B D I A+b D E$ & $Y=a-b T H T-b C C O V$ \\
\hline & $\mathrm{R}^{2}=.358$ & $\mathrm{R}^{2}=.243$ & $\mathrm{R}^{2}=.079$ & $\mathrm{R}^{2}=.142$ & $\mathrm{R}^{2}=.133$ \\
\hline \multirow[t]{2}{*}{ N. Edge } & - & - & - & - & $\begin{array}{c}\mathrm{Y}=\mathrm{a}-\mathrm{bDIA2}+\mathrm{bTHT}+ \\
+\mathrm{bLIT}+\mathrm{bHT}\end{array}$ \\
\hline & & & & & $\mathrm{R}^{2}=.260$ \\
\hline \multirow[t]{2}{*}{ S. Center } & $\begin{array}{c}\mathrm{Y}=\mathrm{a}-\mathrm{bDIA} 2+\mathrm{bBDIA}- \\
\mathrm{bCCOV}-\mathrm{bDE}\end{array}$ & $\mathrm{Y}=\mathrm{a}-\mathrm{bCCOV}-\mathrm{bDE}$ & - & $Y=a+b B D I A=b H T$ & - \\
\hline & $R^{2}=.645$ & $\mathrm{R}^{2}=.427$ & & $\mathrm{R}^{2}=.747$ & \\
\hline \multirow[t]{2}{*}{ S. Middle } & $\begin{array}{c}Y=a-b C C O V+b H T- \\
b H T-b D E\end{array}$ & $\begin{array}{c}Y=a-b B D I A-b C C O V+ \\
\text { bDE }\end{array}$ & - & $Y=a+b D 1 A 2$ & $\begin{array}{c}\mathrm{Y}=\mathrm{a}+\mathrm{bDIA1}-\mathrm{bDIA2}- \\
\mathrm{bCCLOS}\end{array}$ \\
\hline & $R^{2}=.649$ & $\mathrm{R}^{2}=.531$ & & $\mathrm{R}^{2}=.155$ & $R^{2}=.471$ \\
\hline S. Edge & $\begin{array}{l}Y=a+b B D I A+b H T \\
R^{2}=.336\end{array}$ & $\begin{array}{l}Y=a-b D I A 2+b T H T \\
R^{2}=.257\end{array}$ & $\begin{array}{c}Y=a+b C C L O S \\
R^{2}=.086\end{array}$ & - & $\begin{array}{l}Y=a+b H T \\
R^{2}=.257\end{array}$ \\
\hline
\end{tabular}

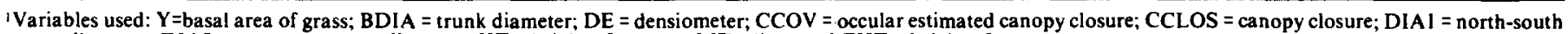
crown diameter; DIA2 = east-west crown diameter; HT = height of canopy, LIT = liter; and THT = height of tree

${ }^{2}$ Dashed lines indicate that the $\mathrm{R}^{2}$ value was not significant $(P>0.05)$ and regression equation was not included.

junipers. This species was never found on the perimeter of the junipers, which may indicate pinyon ricegrass requires a modified microclimate, of lower temperatures and lower light intensities found under the canopy during the growing season.

Stepwise regression analysis was used to select the important independent variables for each location, using basal area of total grass and of each grass species as dependent variables. Many $\boldsymbol{R}^{2}$ values were relatively low, but were included as a basis of comparison with higher values. Only those $R^{2}$ values which were significant $(P<0.05)$ were included in Table 3. Canopy closure appeared to be the most important factor influencing most of the grass species and was negatively correlated with the basal area of the grass species, with the exception of pinyon ricegrass (Table 3 ). These results contrast with those of Jameson (1966). He found no correlation between green production or cover and juniper canopy cover. Jameson (1966) characterized the trees on his study area as being mostly mature and overmature. Typically, older junipers have open canopies, which are off the ground. In contrast, junipers on this study area ranged from immature to overmature. Most of the sampled junipers had canopies which were closed and close to the ground, producing heavy shade.

Crown diameters of the juniper canopies were also negatively correlated with basal area of grasses. Crown diameters are a reflection of how much shading each location receives. The north midcanopy location proved to be an exception for the east-west diameter, which was positively correlated with both total grass and blue grama basal area. Generally, as the size of the juniper increased, so did the canopy diameter; and as the diameter increased, the canopy on the north side opened up and admitted more light. This was reflected by the north side having more open canopy than the south side.

Basal diameter of the juniper trunk, tree height, and height of the canopy tend to be positively related to grass cover. As the juniper grows larger, branches are higher off the ground, admitting more indirect light to the plants under the canopy. Barth (1980) found similar conditions for pinyon pine (Pinus edulis Engelm.) in Colorado. This phenomenon may explain why Jameson (1966) found no correlation between canopy cover and grass cover, because junipers in his study were large and mature.

Litter was negatively related to total grass basal area for the positions adjacent to the trunk and the north mid-canopy location. Litter was also negatively related for blue grama on the north mid-canopy position and for creeping muhly adjacent to the trunk on the north side. With the exception of these 4 models, litter was not an important factor influencing grass cover.

Several factors may be related to the distribution of understory species observed. Shading appeared to be one of the most important factors influencing grass cover although it was not measured directly in this study. All the factors used in the regression models, except litter, influence the amount of light each location receives. As the amount of shading increases, grass cover decreases. With the increased shading, litter fall and litter accumulation likely increase. Thus, allelopathic products from the litter could influence grass cover.

A hypothesis to explain both Jameson's (1966) results and those of this study is that as junipers grow, blue grama and other grasses growing beneath the crown receive less light and eventually these grasses die due to shading. As junipers continue to grow, the canopy becomes higher and more open resulting in more light under the canopy. As the tree grows, litter accumulates under the crown preventing, by mechanical, allelopathic interference, and root competition, grass establishment and spread. Additional research is needed to isolate and separate these influences.

Pinyon ricegrass has an opposite response to shading than that of other grass species. It is a cool-season grass which seems to respond to shade. It is positively related to greater canopy closure, north-south canopy diameter and trunk diameter, and negatively related to greater height of the canopy from the ground, and east-west canopy diameter. As canopy closure and diameter increase, the amount of shade also increases. Pinyon ricegrass requires time to disperse and ecesis, which is shown by its positive relation to trunk size and hence, age.

\section{Literature Cited}

Arnold, J.F. 1964. Zonation of understory vegetation around a juniper tree. J. Range Manage. 47:41-42. 
Balley, O.F., L.A. Daugherty, and G.B. Donart. 1982. Soil survey of the Fort Stanton Experimental Ranch-Phase I. New Mexico State University, Agr. Exp. Sta., Spec. Rep. 43.

Barth, R.C. 1980. Influence of pinyon pine trees on soil chemical and physical properties. Soil Sci. Soc. Amer. J. 44:112-114.

Draper, N.R., and H. Smith. 1966. Applied Regression Analysis. John Wiley \& Sons, Inc. New York.

Everett, R.L., S.H. Sharrow, and R.O. Meeuwig. 1983. Pinyon-juniper woodland understory distribution patterns and species associations. Bull. Torrey Bot. Club. 110:454-463.

Jameson, D.A. 1965. Reduction of understory grass growth by chemicals in litter of juniperus. Proc. 16 an. Meet. AIBS.

Jameson, D.A. 1966. Pinyon-juniper litter reduces growth of blue grama. J. Range Manage. 19:214-217.

Jameson, D.A. 1967. The relationship of tree overstory and herbaceous understory vegetation. J. Range Manage. 20:247-249.

Jameson, D.A. 1970. Juniper root competition reduces basal area of blue grama. J. Range Manage. 23:217-218.

Johnsen, T.N. 1962. One-seed juniper invasion of northern Arizona grasslands. Ecol. Monog. 32:187-207.

Lavin, F., D.A. Jameson, and F.B. Gomm. 1968. Juniper extract and deficient aeration effects on germination of six range species. J. Range Manage. 26:262-263.
Lemmon, P.E. 1956. A spherical densiometer for estimating forest overstory density. Forest Sci. 2:314-320.

Ott, L. 1977. An introduction to statistical methods and data analysis. Duxbury Press. North Scituate, Mass.

Pieper, R.D., J.R. Montoya, and V.L. Groce. 1971. Site characteristics on pinyon-juniper and blue grama ranges in south central New Mexico. NMSU Agr. Exp. Sta., Las Cruces. Sta. Bull. 573.

Ripple, P.B. 1978. Cabling in the pinyon-juniper ranges of south-central New Mexico. M.S. thesis. New Mexico State Univ. Las Cruces .

Skau, C.M. 1960. Some hydrologic characteristics in the Utah juniper type of northern Arizona. Ph.D. Thesis, Michigan State Univ., East Lansing. Springlield, H.W. 1976. Characteristics and management of southwestern pinyon-juniper ranges: The status of our knowledge. USDA Forest Serv., Rocky Mt. Forest and Range Exp. Sta., Res. Pap. RM-160.

Strickler, G.S. 1959. Use of the densiometer to estimate density of forest canopy on permanent sample plots. USDA Forest Serv., Pac. N.W. Forest and Range Exp. Sta. No. 180.

West, N.E., K.H. Rea, and R.J. Tausch. 1975. Basic synecological relationships in pinyon-juniper woodlands. In: Gifford, G.F. and F.E. Busby (Eds.) The pinyon juniper ecosystem: A symposium. Utah State Univ., Utah Agr. Exp. Sta., Logan Utah. 